\title{
Urban Development and the (Re)use of the Communist-Built Industrial and Agricultural Sites after 1990. The Showcase of Bucharest-Ilfov Development Region
}

\author{
Ines Grigorescu ${ }^{1}\left(\mathbb{D}\right.$, Cristina Dumitrică ${ }^{1, *}\left(\mathbb{C}\right.$, Monica Dumitrașcu ${ }^{1}\left(\mathbb{D}\right.$, Bianca Mitrică $^{1}\left(\mathbb{C}\right.$ and Costin Dumitrașcu ${ }^{2}$ \\ 1 Institute of Geography, Romanian Academy, 023993 Bucharest, Romania; inesgrigorescu@yahoo.com (I.G.); \\ stefania_dumitrascu@yahoo.com (M.D.); biancadumitrescu78@yahoo.com (B.M.) \\ 2 Faculty of Geography, University of Bucharest, 030018 Bucharest, Romania; costin_dumitrascu@yahoo.com \\ * Correspondence: geocrisro@yahoo.com; Tel.: +40-721-527-607
}

Citation: Grigorescu, I.; Dumitrică, C.; Dumitrașcu, M.; Mitrică, B.; Dumitrașcu, C. Urban Development and the (Re)use of the

Communist-Built Industrial and Agricultural Sites after 1990. The Showcase of Bucharest-Ilfov Development Region. Land 2021, 10, 1044. https://doi.org/10.3390/ land10101044

Academic Editor:

Alexandru-Ionuţ Petrişor

Received: 16 August 2021

Accepted: 2 October 2021

Published: 5 October 2021

Publisher's Note: MDPI stays neutral with regard to jurisdictional claims in published maps and institutional affiliations.

Copyright: (c) 2021 by the authors. Licensee MDPI, Basel, Switzerland. This article is an open access article distributed under the terms and conditions of the Creative Commons Attribution (CC BY) license (https:// creativecommons.org/licenses/by/ $4.0 /)$.

\begin{abstract}
Urban development and changing the patterns of industry and agriculture had caused the foremost spatial and functional transformations of the post-communist period in Romania. These changes have resulted in increased land consumption, often including the reuse of abandoned or non-residential built-up areas (e.g., industrial, agricultural). By integrating spatial and statistical data, the current analysis has revealed as key features: spatial shrinkage, fragmentation, functional diversification, tertiarization and change of patterns. Using a functional change matrix, five main (re)use types have been identified and quantified: maintenance, conversion, replacement, abandonment, and demolition. Overall, between 1990 and 2018, over 50\% functional losses have been recorded.
\end{abstract}

Keywords: urban development; built industrial and agricultural sites; Bucharest-Ilfov development region; Romania

\section{Introduction}

Urban development, mainly through urbanisation and suburbanisation, is the leading driver of the most important types of land use changes worldwide, and the reuse of built industrial heritage has been a common practice in a growing number of cities [1]. In the past century, the Central Eastern European cities, in particular, have developed primarily under the influence of two different societal systems: the communist (pre-1990) and the post-communist (post-1990). The fall of the communist regime marked drastic changes in their economies by replacing the old centralised system with the free-market system that is reflected in the urban development of their cities [2,3]. It also involved significant spatial transformations (i.e., changes in the land use/land cover pattern) driven by the decollectivisation of agriculture, change of land property, privatisation or deindustrialization processes [2,4-6]. The urban development policy has evolved and changed more rapidly [7], facing new challenges of the so-called transition and post-transition periods [2,5] which included the EU joining period (2007) and EU Urban Agenda. The most relevant challenges of Central Eastern European cities are governance, an integrated perception of a city with its hinterland (metropolitan planning), and financialisaton [7]. Thus, the complexity of the functional and spatial transformations was powered by the accelerated urbanisation processes of the neoliberal economies, the major development of infrastructures driven by the arrival of the EU cohesion funds and foreign multinational investments [3], and the intensive land consumption and conversion for new urban use (residential, commercial, industrial, recreational or other) [5,8]. Under the continuous urban transformation, most cities have experienced, in the past decades, reshaping of former built industrial and agricultural spaces, which have become key consequences of the spatial and functional transitions occurring in- and outside city boundaries. These units (especially post-industrial) are generally located in advantageous locations (within or 
near city centres) and are characterized by special architectural and technical features, as well as by large spaces suitable to be reused for new functions, making them important drivers for urban (re)development $[9,10]$. They are frequently left deteriorated, as they are not considered as important as other heritage structures for preservation [10], which drives a significant increase in the amount of unused space, often called brownfields [11], to be used as available land resource under rapid urbanisation (including urban regeneration) and suburbanisation processes [6]. In post-socialist countries, suburbanisation has become the most important urban process contributing to reshaping morphology, land use patterns, and socio-economic structure of cities and their surrounding territories [12]. However, despite the extended body of knowledge on post-communist urban multiple transformation dynamics in relation to certain factors, i.e., the political, social, economic and cultural transition to capitalism and a market economy [3,13-18], the urban transition in relation to the former industrial and agricultural sites is less studied. There is, however, among the post-communist experience, evidence of the eastern German, Czech and Polish cities that are seeing signs of reurbanisation and regeneration through new inner-city growth and core city stabilisation [19-21]. Despite that, Sýkora and Bouzarovski [16], have pointed to an uneven knowledge of the multiple transformations of the post-communist cities, with an over-representation of cities such as Budapest, Prague, and Warsaw, followed by Ljubljana, Tallinn, Moscow, and Sofia. These studies have particularly analysed the spatial and temporal changes of the urban and suburban landscape in relation to certain key structural and functional suburbanisation-related processes (e.g., urban sprawl, land conversion, housing development) or de-agriculturalisation [21]. The existing analyses were centred on cities or metropolitan areas such as: Prague [12,22,23], Budapest [24-27]) Tallinn [28,29], Sofia [30-32], Warsaw [33-36], Cracow [37], Katowice, Wrocław, Łódz, and Gdansk [38], Wroclaw [39,40], Poznań [41], Bucharest [5,6,42-47], Bratislava [18,23], etc.

According to Sýkora and Bouzarovski [16], the complexity of the post-communist transition of a city involves a three-tier transformation: (1) institutional, which creates the general societal framework for transition, (2) social, economic, cultural and political, shown in the life of people, companies and institutions and resulting in social restructuring, and (3) urban change dynamics. The same authors refer to a common logic in the development of post-communist cities (in terms of morphology, land use and social segregation) that provides a set of examples able to impact other cities of regions. However, throughout this complex transformation, the economic restructuring process, which involves deindustrialisation, plays a significant role. The reuse of built industrial and agricultural sites has been a delayed process in the Central and Southeast European post-socialist countries (e.g., Czech Republic, Poland, and Romania) compared to the Western European countries (e.g., Great Britain, France, former West Germany) due to long-term experiences the latter have had with brownfields [11]. This process emerged in the 1970s in Western Europe as a long and less intensive process subsequent to massively declining mining, heavy industries, and textiles. In the Central and Southeast European countries, it started to appear more recently (after 1989, following the collapse of the Eastern Bloc and the transition to the market economy), being characterised by an intensive progress [11,19,48]. It generally included, apart from the former industrial sites, the post-agricultural areas $[40,49]$, i.e., some of the assets of the communist agriculture (e.g., state farms, greenhouses), which following privatisation, land reforms and farm restructuring, they become available in the urban development process.

In Romania, the profound socio-economic transformations conditioned by the transition from a centralised to a market-based society had significantly impacted two major fields: agriculture via decollectivisation, privatization and re-ownership, and industry via deindustrialization and restructuring. Through the abandonment of agricultural land or post-industrial sites, both fields have released important amounts of land resources into the real estate market to be easily converted into other land use categories (e.g., residential, commercial, and logistic). As a consequence, changing the patterns of industry had caused significant spatial and structural transformations. Moreover, in recent decades, 
post-industrial sites have received increasing attention, since vacant agricultural or natural lands prone to urban development have become less available, more expensive and more protected in dense populations [11].

There are two main groups of topics that most studies referring to built industrial and agricultural sites (post-industrial sites, in particular) generally discuss: heritage-oriented, as a combination of cultural industry and heritage conservation, which involves the reuse of post-industrial buildings (e.g., mills, warehouses, railway stations, and factories) that lost their function and became abandoned or underused [1,10,50-55]; and developmentoriented through the adaptive (re)use of post-industrial sites under brownfields regeneration [11,56] and urbanisation and suburbanisation processes [37,57]. The discussion about the reuse of built industrial and agricultural sites under urban development processes, in particular, is related to the new functional transitions and patterns identified within several urban systems, e.g., cultural and touristic [38,50,53,58,59], urban regeneration $[1,21,37,48,60-65]$, sustainable urban development [51], or the shift towards creative industries [66,67]. Holistic approaches using qualitative and quantitative criteria $[10,68]$, or models and strategies $[69,70]$ to support the decision-making process for the reuse and redesign of different abandoned industrial assets have been carried out for several regions of the world (e.g., northern Italy and Hong Kong). In addition, studies have been focusing on different methodologies to identify critical factors influencing the local sustainable development through adaptive reuse projects, i.e., Fuzzy approach [71,72].

Studies carried out for the Romanian territory have not sufficiently examined the (re)use of built industrial and agricultural sites in relation to urbanisation and suburbanisation processes. Most national-level studies have focused on post-industrial sites in terms of the identification and analysis of several typologies and patterns across Romania in relation to the underlying driving factors of the post-communist period. Hence, under specific spatial constraints and development opportunities, Filip and Cocean [73] recognized three types of post-industrial sites or brownfields: compact, bipolar compact and dispersed. Based on several models of technical and industrial heritage reuse and the differentiated behaviour of urban metabolisms, Cercleux et al. [57] provided a general classification of Romanian cities: in harmony, in disharmony, and indifferent. Merciu et al. [74,75] identified and described models of good practice of cultural conversions of the Romanian industrial heritage emphasising their importance and value as cultural resources. Cobârzan [76] developed a quantitative and qualitative analysis of the scale and nature of brownfield sites in Romania in order to provide policy recommendations to support their regeneration.

More focused regional- and local-level studies have been centred on the effects, reuse and evolution patterns of brownfields in several cities or regions: typologies (derelict, unoccupied or abandoned and residential) and redevelopment models (self-development and assisted development) in Craiova [77]; integrating brownfields into urban redevelopment strategies in Timișoara [78]; effects of post-socialist deindustrialization [79] and urban integration of post-industrial sites [80] in Bucharest; theoretical and practical aspects of regeneration of decommissioned industrial areas in Oradea [64], Lugoj [81] or Ștei [60]. Studies on the ecological revitalisation of post-industrial sites or brownfields have generally considered the renewal of industrial polluted sites which included mining areas, i.e., Petroșani [59] or heavy industry, i.e., Galați [82] as a prerequisite to sustainable urban development. Perception studies have referred to the relationships between the community, the industrial heritage and central authorities in a mining city-Petrila [83], or to the landscape revitalization of industrial space in two factory buildings in Sinaia town [84]. Despite the vast literature on the abandoned industrial assets taken over in the urban development process through replacement or conversion, the authors identified knowledge gaps in the narrative review related to the inclusion of former (communist) built agricultural units as spaces suitable to be reused in the urban development process. As a result, the current study is seeking to examine and compare the (re)use of both types of former built communist sites-industrial and agricultural-under urbanisation and suburbanisation processes driven by the socio-economic and spatial transformations of the communist (intensive and 
extensive agriculture, forced industrialization) and post-communist (decollectivisation and privatisation of agriculture, industrial decline, deindustrialization and industrial relocation) periods. To meet this main goal, the key research questions of the paper are: (1) to identify, map and analyse the former communist industrial sites (pre-1990), (2) to identify their current functions and use (post-1990) in order to (3) identify adaptive (re)use patterns able to spot their path towards urban development of heritage conservation. The study focuses on Bucharest-Ilfov development region which is composed of the capital city (Bucharest) and its surrounding territory (Ilfov County) (Figure 1).

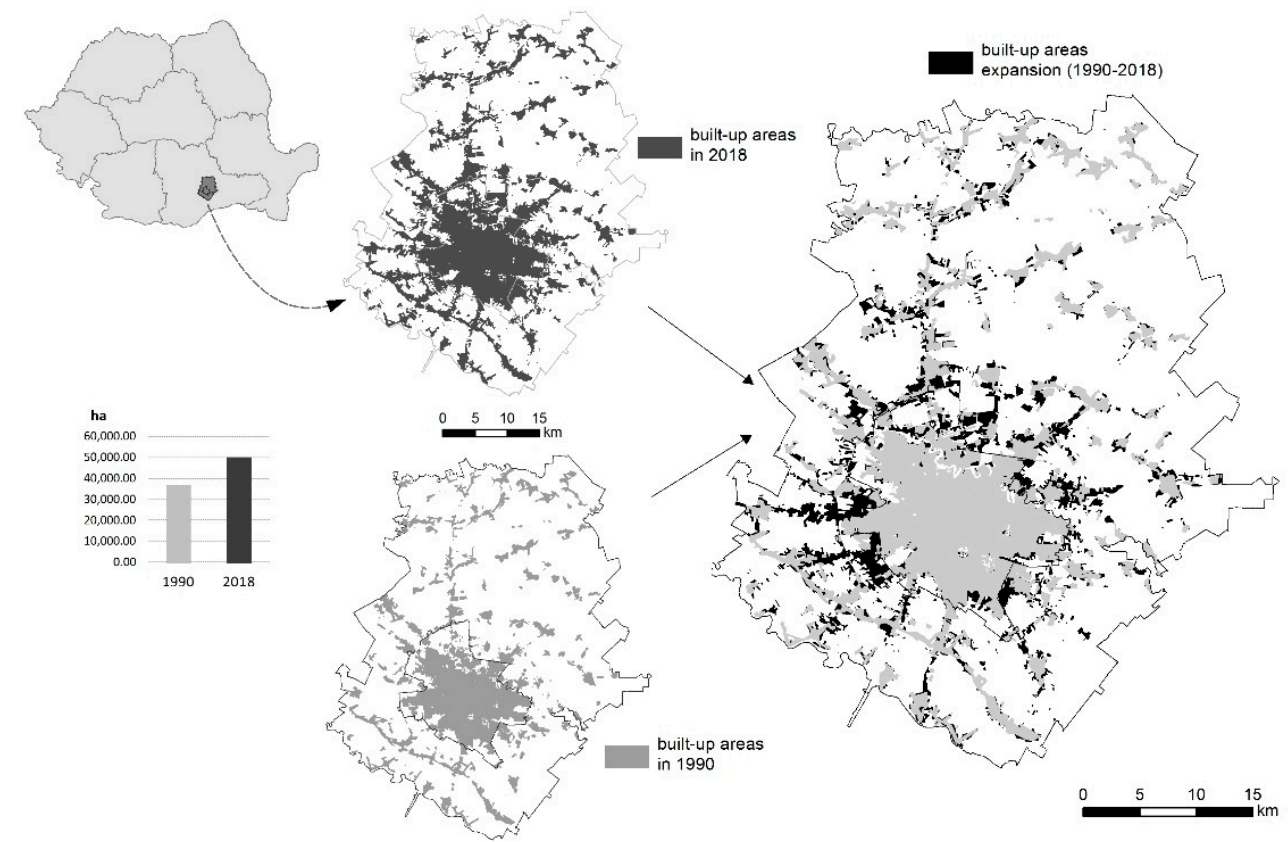

Figure 1. Built-up areas expansion in Bucharest-Ilfov development region (1990-2018).

\section{General Context of Spatial Transformations in Romania: From Deindustrialization and Agricultural Restructuring to Post-Communist Urban Development}

The spatial and functional transformations of the last century, generally driven by the continuous population growth, required the expansion of agricultural areas for extensive and intensive farming and forced industrialization processes [45]. Thus, both agriculture and industry were the main economic branches which drove the dynamics of the urbanisation processes and the related spatial development throughout the last century. The development of agriculture and the industrialization processes, which began to expand in the 20th century shortly after its independence $(1877 / 1878)$ and unification (1918) of Romania, have rapidly evolved during the communist period, when it became crucial for the economic development of the state. Following the implementation of the Sovietbased planned development model with a focus on the heavy industry, manufactures were updated and newly equipped, others, of great capacity, were being built [85]. Thus, the explosive development of industrial activities in the second half of the last century, especially within cities, generated a particular pattern of urban space organization. This included the industrial platforms, usually located on the outskirts of cities that were specially designed spaces to host production activities $[85,86]$. The Soviet-based planned development model also affected agriculture. Thus, following the land reform of 1945 (enforced after the Second World War), the property of great landowners was liquidated, enabling the transition to socialist agriculture $[87,88]$. The collectivisation of agriculture and the expansion of the state-owned farms led to the development of a significant number of such units in the outskirts of main cities and in their surrounding rural areas. After the fall of communism (1989), the economic transition from the centralised to the market system brought about fundamental transformations in agriculture and industry, and the collective and state prop- 
erty was replaced by private property. The assets of the state-owned agricultural units (e.g., farms, greenhouse) underwent significant transformations following the decollectivisation and privatisation processes. The industrial restructuring [89], which in its early stages, took on diverse forms: steep decline, closing of factories, massive layoffs, followed by negative social and economic effects that slowed down the privatisation process and discouraged foreign investments [90]. Given the strong industrial development during the communist period, industrial restructuring in post-communist Romania was, to a large extent, synonymous with deindustrialization. Moreover, its highest concentration in urban areas explains why cities were most affected by deindustrialization $[85,91]$. The decline of urban industry determined the closure of many industrial enterprises or the reduction of activity in others; big cities, in particular, registered the strongest decline of the industrial labour force. It was also the case of Bucharest, whose industry was abandoned, relocated or subjected to new specializations (e.g., services, creative industries). In addition, in the proximity of large cities, following the decollectivisation and privatisation of agriculture, new types of relationships between the surrounding rural territories and urban areas emerged. As a result, the urban-rural fringe has become progressively shifted further to the surrounding rural agricultural space, the first to be consumed as a land resource in the (sub)urban development process [45]. The agricultural and industrial restructuring process generated a significant amount of abandoned spaces, continuously under degradation, thus becoming "problem spaces" for urban development [90] which can become sources for land use conflicts [85]. The development of cities involved not only a functional diversification, but also a significant spatial expansion through urbanisation and suburbanisation processes $[6,46]$, consuming in most of cases, former agricultural and industrial sites. Thus, in the case of large cities, the former state-owned agricultural enterprises and industrial platforms, initially located on the periphery or in the surrounding of large towns, were integrated into the urban space, replaced or surrounded by residential areas. In the particular case of industrial platforms, especially in the small urban centres, they have remained at the edge of cities [85].

\section{Study Area: Bucharest-Ilfov Development Region}

The study area is one of Romania's eight development regions-NUTS 2, which was established in 1998 as territorial-statistical entities without legal personality in order to provide data for Eurostat estimations and for the absorption of European structural funds [92]. Bucharest-Ilfov development region is located in the southern part of Romania (central Romanian Plain) and is one of country's main agricultural regions. The area was subject to significant man-made environmental changes driven by urban development, agriculture and industry in relation to the natural conditions and the contextual socioeconomic factors [93]. The gradual transition from the traditional rural-agrarian to the urban-industrial society [4] was followed by the spatial and structural changes brought in by the fundamental political and socio-economic transformations of the post-communist period [45]. The study area includes the municipality of Bucharest, the capital of Romania, and Ilfov county which surrounds it. It holds $11.5 \%(2,498,967$ inhabitants at 2011 census) of Romania's population and only $0.8 \%$ of its territory $(1821.15 \mathrm{sq} . \mathrm{km})$, being the smallest development region [94]. Since the first half of the 19th century, the city of Bucharest has been home to important industrial activities (mainly agricultural-based) in the fields of corn-grinding, leather dressing, textiles and food. The industrial tradition was continued during the inter-war period with a diversification of the industrial activities (e.g., machinebuilding, chemical, and textile). In 1938, a peak year of the inter-war Romanian economy, Bucharest concentrated on one-fifth of the industrial production, primarily of the light and food industry. During the communist period, the south of the country was dominated by the Bucharest-Ploiesti axis. In this way, the capital became the leading industrial centre of Romania, producing a wide range of items [90], the largest number of employees in the industry and most important in terms of national industrial production. However, after 2013, Bucharest registered lower shares than the national average. Currently, almost two- 
thirds of foreign direct investments (FDI) are concentrated in Bucharest-Ilfov development region; Bucharest maintains its supremacy by hosting foreign companies or only their registered offices [85]. Conversely, Ilfov county has a mixed profile: services-industrial in the proximity of the capital city and rural-agricultural in the rest. The latter has been maintained, to a certain extent, from the communist period when it used to be part of one of Bucharest's subdivisions ("Sectorul Agricol Ilfov") set up with the aim of supplying the city with agricultural products.

The evolution of the inter-communal relations at the rural-rural, rural-urban/urbanrural levels, as well as the way of rural settlements set-up, made the demographic size vary greatly $[95,96]$. The 32 rural LAUs (local administrative units) /communes range from a minimum of 2674 inhabitants (inh.) in Dărăști-Ilfov to a maximum of 18,477 inh. in Chiajna. One of the communes, e.g., Jilava, Cernica, Dobroești, and Brănești, has a demographic size close to the urban dimension. The demographic size of urban LAUs/towns vary from 10,554 inh. in Măgurele to 2,114,236 in the case of Bucharest municipality. The towns are included in the following categories: 4 (between 10,000 and 20,000 inh.) and 5 (between 20,000 and 50,000 inh.) and Bucharest Municipality with over 2 million inh.

Since 1992, the dynamics of the population show a slow increase in terms of the absolute value (from 2.46 million in 1992 to 2.50 million in 2018, meaning an increase of $1.77 \%(43,611$ inhabitants)). The population dynamics registered a negative trend in the cases of four LAUs, a positive one for 35 LAUs and stagnant for one LAU: the highest decrease is registered by Nuci LAU $(-19.0 \%)$ followed by Dărăști-Ilfov $(-10.4 \%)$, Gruiu $(-4.2 \%)$ and București municipality $(-4.0 \%)$; Vidra LAU registered a stagnant evolution; a slow increase (between 1.7 and $25.0 \%$ ) is registered in the case of seven LAUs; moderate increase (between 25.1 and 50.0\%) for 14 LAUs; high increase (between 50.1 and 100.0\%) for six LAUs; very high increase (over 100.1\%) for Popești-Leordeni and Bragadiru urban LAU and Chiajna rural LAU (Figure 2).

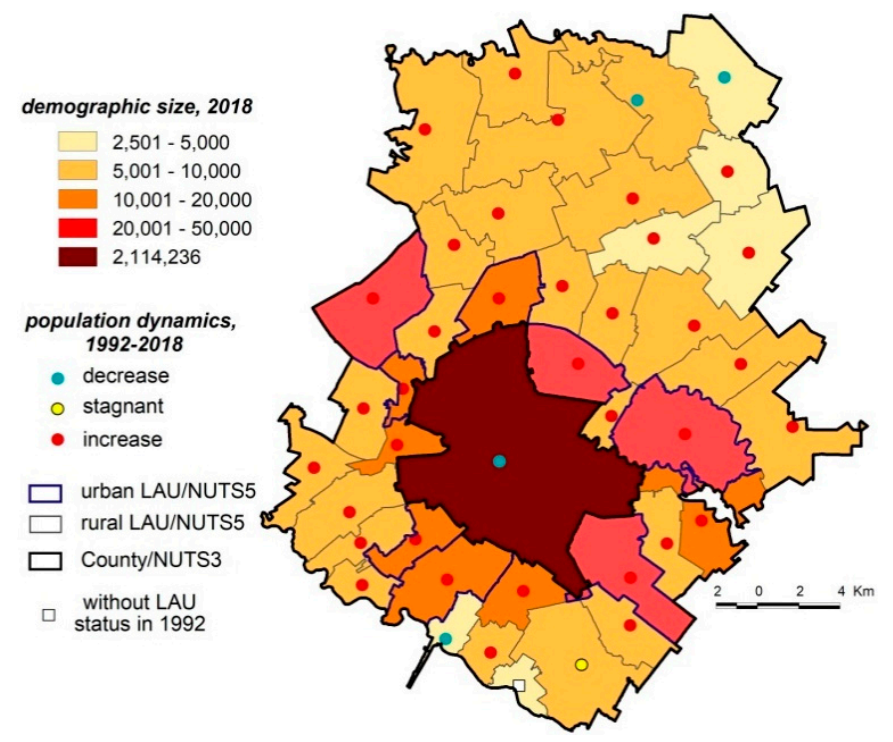

Figure 2. Population dynamics over the 1992-2018 period.

The demographic increase of the area is given by the town status gain by some rural LAUs located in Ilfov County. Numerous residents from the capital city moved their residence to the newly transformed towns, thus helping increase the local population. Numerous residents from the capital city moved their residence to the newly transformed towns, thus helping increase the local population. An important phenomenon Romania's large cities are facing is the centre to the outskirts and blocks-of-flats to one-family dwellings or new residential districts migration $[42,97]$. Thus, changing the spatial distribution of population according to its socio-economic status (residential suburbanisation) is reversing the 
traditional social and spatial patterns of the communist city characterised by the declining of the socio-economic status of population with distance from the centre $[12,42,96,98]$.

In the process of agricultural and industrial restructuring of Bucharest-Ilfov development region, two main types of spatial transformations have related land use/cover change with urban expansion: the relocation of some companies in Ilfov County and the conversion of former agricultural assets and industrial sites through abandonment and/or reuse. The latter have made available significant land resources for future use (e.g., residential, commercial) in relation to the continuous urban development. Thus, between 1990 and 2016, built-up areas have grown from 36,961 to 50,075 ha, the largest extent being registered by Ilfov County (63.6\%) (Figure 1), mainly driven by land availability (arable and post-industrial) and suburbanisaton processes $[5,6]$.

The socio-economic consequences of the agricultural and industrial restructuring which occurred after 1990 are also mirrored in the share of employed population, which drastically shrank after 1990 in some agricultural- (e.g., Nuci, Copăceni) and industrialdependent (e.g., Jilava) communes. In Bucharest and the surrounding communes (e.g., Bragadiru, Chiajna, Corbeanca), under the extended urbanisation and suburbanisation processes, the relocation of some industrial units, and the emergence of new commercial and residential development, a significant increase of the employed population has been registered. The share of an employed population on economic sectors best reflects the shifts between primary/secondary and tertiary sectors. Thus, in 1990, which mirrors the communist context, most of the LAU located in the proximity of Bucharest (e.g., Glina, Jilava, Popești-Leordeni) registered the highest shares of population employed in the secondary sector (over $70 \%$ ), while in the tertiary sector, the shares were well below 50\% with highest values in Snagov, Bucharest and Ștefăneștii de Jos. The 2011 census, which reflects the consequences of the post-communist agricultural and industrial restructuring, shows significant shifts between secondary and tertiary sectors. Most of LAU have registered an increase in the shares of population employed in the tertiary sector, while Bucharest and some small towns located in its proximity (e.g., Otopeni, Voluntari) have recorded values of up to $80 \%$.

\section{Materials and Methods}

For the current investigation, the authors used a series of cartographical materials (topographic maps, topographic plans, and satellite images, including Google Maps) at fairly detailed scales (e.g., 1:25,000, 1:2000) (Table 1, Figure 3) in order to accurately identify and map the built industrial and agricultural sites operational during (1) the communist period (pre-1990) and distinguish their use and spatial patterns after (2) the fall of communism (post-1990).

Table 1. Cartographic sources and satellite images used.

\begin{tabular}{|c|c|c|c|c|}
\hline \multicolumn{5}{|c|}{ Maps } \\
\hline \multicolumn{2}{|c|}{ Source } & \multicolumn{2}{|c|}{ Year } & Scale \\
\hline \multicolumn{2}{|c|}{ Topographic map } & \multicolumn{2}{|c|}{ 1974-1978 } & $1: 25,000$ \\
\hline \multicolumn{2}{|c|}{ Topographic plan } & \multicolumn{2}{|c|}{ 1967-1985 } & 1:2000 \\
\hline \multicolumn{5}{|c|}{ Satellite images } \\
\hline source & year & data & Path/row & resolution \\
\hline \multirow{2}{*}{ LANDSAT 4-5 TM } & \multirow{2}{*}{1990} & 07 July & $182 / 029$ & \multirow{2}{*}{$30 \mathrm{~m}$} \\
\hline & & 21 August & $183 / 029$ & \\
\hline \multirow{2}{*}{ LANDSAT 8 OLI_TIRS } & \multirow{2}{*}{2016} & 09 April & $182 / 029$ & \multirow{2}{*}{$30 \mathrm{~m}$} \\
\hline & & 07 July & $183 / 029$ & \\
\hline \multirow{2}{*}{ SENTINEL—2A, 2B } & \multirow{2}{*}{2018} & 06 January & $206 / 050$ & \multirow{2}{*}{$10 \mathrm{~m}$} \\
\hline & & 01 May & $206 / 050$ & \\
\hline
\end{tabular}




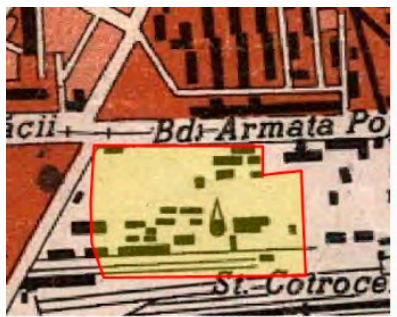

Topographic map scale 1:25,000

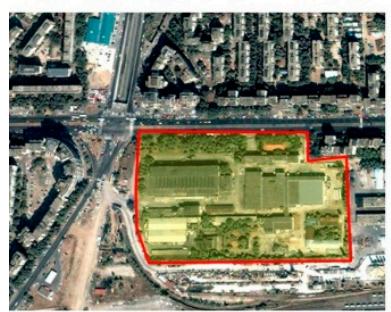

Satellite image 1990

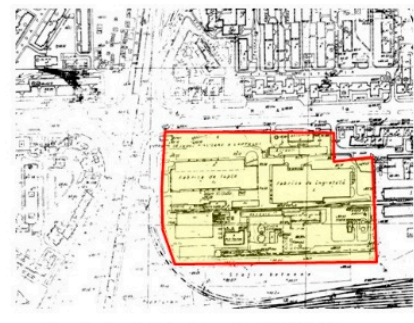

Cadastral map scale 1:2,000

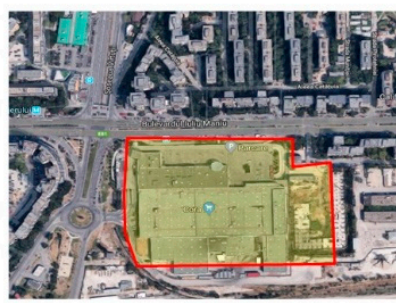

Satellite image 2018

Figure 3. Cartographic sources and satellite images used for the statistical and spatial analyses (case study: Titan Dairy Factory turned into Cora Hypermarket).

The reason behind choosing the two periods is that they have different socio-economic characteristics which have influenced the evolution of the Romanian economy: (1) the centralisation of agriculture (intensification, extensification, collectivisation and state farms), forced industrialization and urbanisation and (2) a changeover in the economy meant to replace the old centralised system by the free market system; agriculture (decollectivisation and privatisation) and industry (deindustrialization and industrial relocation) were the two main fields to be significantly transformed [2].

In order to highlight the consequences of the restructuring in agriculture and industry (e.g., layoffs, unemployment), the study was completed by the dynamics of the employed population and the shifts between the economic sectors based on the socio-economic data extracted from the available national censuses $(1992,2011)$ at Local Administrative Unit (LAU) level. In order to easily track the current vs. former use of the built industrial and agricultural sites, the authors have framed them into 8 main categories according to their past and current functions, grouped two-tier (levels) (Table 2) which includes agro-food (which also incorporates animal husbandry farms and greenhouses), textile, wood, chemical and pharmaceutical, building materials, metallurgy, machine building, energy, air, road and rail transport, commercial, residential, services, abandoned areas. The category named others includes built-up space and functional uses which were difficult to distinguish.

An important aspect of the analysis was to categorise the new spatial patterns of built industrial and agricultural units in relation to their former and current functions and state (maintenance, conversion, replacement, abandonment and demolition) and relate them to the main potential drivers of change (e.g., location in relation to the built-up areas, legislative measures, urban planning).In the first stage, the comparative analysis of each built industrial and agricultural site (current state and use vs. former use) enabled the authors to identify the functional transformations that occurred after 1990 and to select five typologies and patterns of post-industrial (re)use under urbanisation and suburbanisation processes:

Maintenance - the built industrial and agricultural units continue to maintain their use in the its original building;

Conversion - the industrial and agricultural units have another use; the building is maintained, but the function is different (e.g., commercial, residential, other type of industry);

Replacement-the industrial and agricultural units have been totally replaced by other building with a different function; 
Abandonment - the industrial and agricultural units (the building together with its annexes and the surrounding terrain) have been abandoned, thus being prone to further types of reuse (conversion, replacement or even demolition);

Demolition - the buildings located on the site of the industrial and agricultural units have been demolished; this type of reuse is the most invasive in terms of urban development and preservation of industrial/cultural heritage.

Table 2. Former and current use of the built industrial and agricultural sites.

\begin{tabular}{|c|c|}
\hline Level I & Level II \\
\hline \multicolumn{2}{|c|}{ Research \& Development Institutions (1) } \\
\hline \multirow{8}{*}{$\begin{array}{l}\text { Industrial and } \\
\text { agricultural units (2) }\end{array}$} & Agro-food (21) \\
\hline & Textile (22) \\
\hline & Wood (23) \\
\hline & Chemical and Pharmaceutical (24) \\
\hline & Building materials (25) \\
\hline & Metallurgy (26) \\
\hline & Machine building (27) \\
\hline & Energy (28) \\
\hline \multirow{3}{*}{ Transport (3) } & Air (31) \\
\hline & Road (32) \\
\hline & Rail (33) \\
\hline \multicolumn{2}{|c|}{ Commercial (4) } \\
\hline \multicolumn{2}{|c|}{ Residential (5) } \\
\hline \multicolumn{2}{|c|}{ Services (6) } \\
\hline \multicolumn{2}{|c|}{ Abandoned (7) } \\
\hline \multicolumn{2}{|c|}{ Others (8) } \\
\hline
\end{tabular}

In the second stage, with the help of a functional change matrix (Figure 4), the authors were able to evaluate the dominant typologies by which each built industrial and agricultural site changed its function (conversion, replacement, abandonment, demolition) or maintained it (maintenance) after 1990.

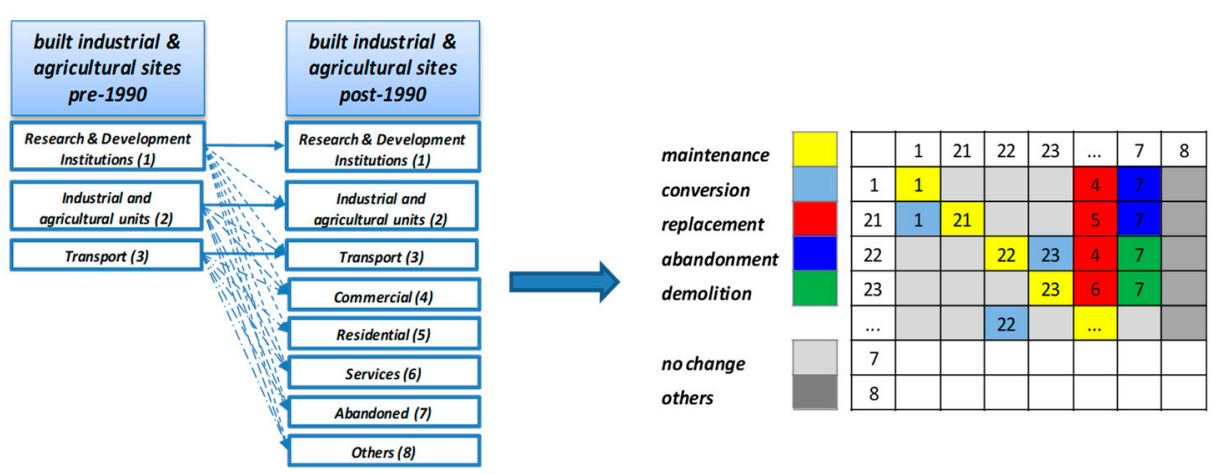

Figure 4. Functional change matrix.

The identified dominant typologies will further help identify and explain the spatial and functional patterns which reflect transformations and future patterns of spatial transformations and the relationships with urban development. At the same time, one can identify their bivalent potential of being integrated into urban development projects or into heritage conservation projects. In this way, the transformation flows can contribute either to urban development (urban development-oriented) or to heritage conservation (heritage-oriented). 


\section{Results}

This section may be divided by subheadings. It should provide a concise and precise description of the experimental results, their interpretation, as well as the experimental conclusions that can be drawn. The inter-war and communist industrialization and development of agriculture placed most of industrial units (e.g., heavy, food, textile, wood) inside the city limits and at its current outskirts (then industrial-residential neighbourhoods). Because of the predominant rural-agricultural profile of Ilfov County, the primary food industry (e.g., animal farms, greenhouses) was located outside city limits. During the communist period, most of the industrial sites were located in the planned working class neighbourhoods: 23 August Plants (heavy industry, totally disbanded) in Pantelimon Neighbourhood; Cesarom (building materials, largely disbanded), Turbomecanica (engines, totally disbanded) in Militari Neighbourhood. Other industrial units were positioned in the city's outskirts, some of which are currently integrated into the city, e.g., in Ilfov County: Pipera Industrial Zone with several factories and research centres in the field of electronics, computers, automatics or furniture; Băneasa-Otopeni Industrial Zone with aircraft and heavy industry, generally dismantled. Most of the state-owned farms (initially part of the former agricultural subdivision of Bucharest- "Sectorul Agricol Ilfov") were located not far from the city limits in Otopeni (dairy farm), Chitila (poultry farm), Buftea (poultry farm); Domnești (greenhouses) etc. In the process of restructuring in agriculture and industry (post-communist period), most of the industrial units were closed, abandoned or dismantled. Few of them host different activities in the former assets and fewer kept their original function. As a result, in the 1990-2018 period, a shrinkage from 6536.3 to 2791 ha units was recorded, which means that nearly $60 \%$ of built industrial and agricultural units have lost their initial use (Figure 5). In addition, before 1990, the units were mainly industrial and were compacted and almost monolithic (totalling 491 units); after 1990, they became highly fragmented (708 units) both spatially and functionally, enabling their transition from their initial function to another (Figure 6).

Of the total loss of $3745.3 \mathrm{ha}$, almost $35 \%$ have turned into residential, commercial and business as a consequence of urban development, and almost $24 \%$ have been abandoned, a precursor of urban development through their availability as land resources for further built-up areas expansion. The most significant spatial shrinkage was recorded by the agro-food, building materials and machine building industrial branches with up to a $72 \%$ to $76 \%$ decrease of industrial use. In terms of fragmentation of industrial and agricultural units, the most representative transformation, with up to a $54 \%$ breakup, was experienced by the building materials (from 19 to 42 units), agro-food (from 64 to 119 units), chemical and pharmaceutical (from 22 to 38 units), and metallurgy (from 16 to 23 units) industrial branches (Figure 7). This overall spatial and functional development falls into the path of most post-communist cities, which following the economic restructuring, deindustrialisation and tertiarisation processes occurred. The resulted brownfields made room for central and inner-city urban restructuring and redevelopment through the replacement of existing activities (mainly industry and agriculture) with more economically efficient uses, i.e., commercialisation, business offices, and residential [3,12,15-17,48,56]. Consequently, this process of transformation of the post-industrial brownfields and of post-agricultural areas to other more economically profitable uses have taken several forms which involved more drastic, sometimes irreversible changes, but also smoother ones. However, both situations lead, upon case, either to new urban development or urban restructuring and heritage conservation. 


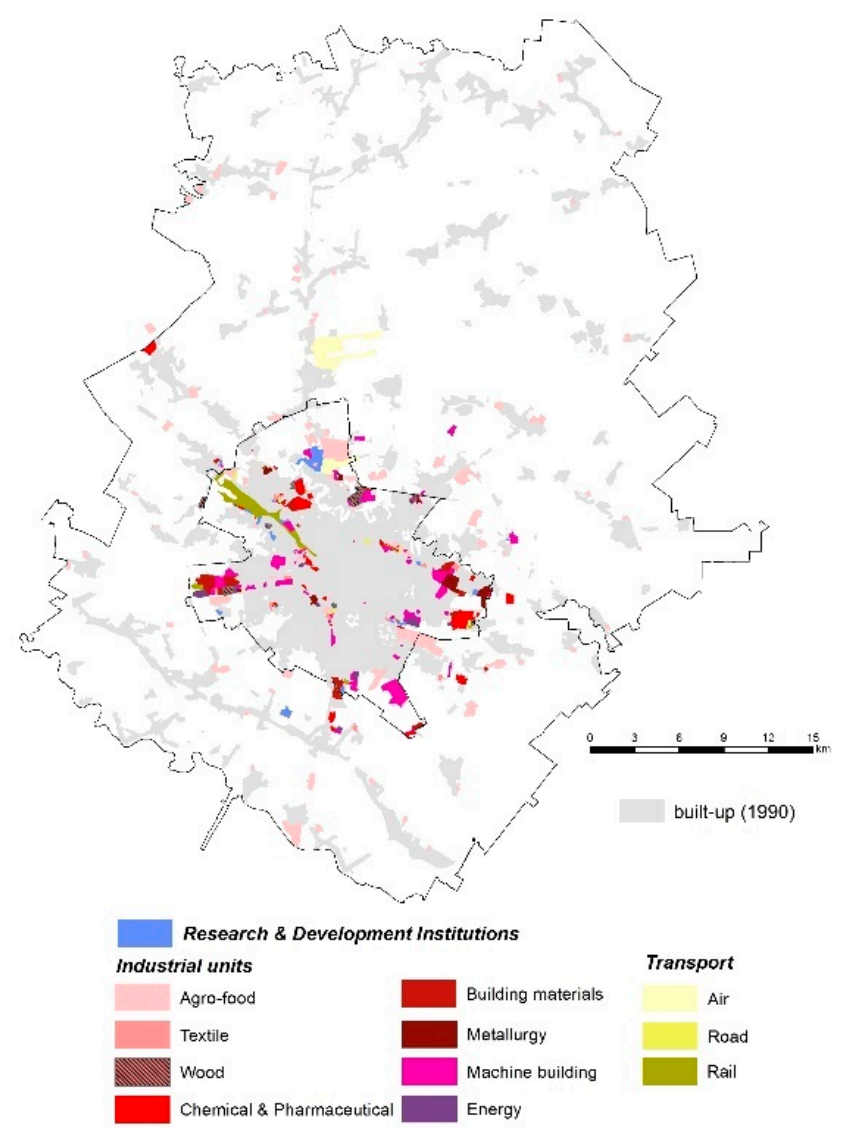

Figure 5. Spatial distribution and functional use of built industrial and agricultural sites (1990).

As the functional change matrix shows, after 1990, most of sites underwent replacement of the 1 to 27 initial positions (research \& development institutions and industrial units with different functional profiles) mainly with 4-5 (commercial and residential) and less with 6 (business) positions. To a significant extent, the initial 1 to 27 positions have also been subject to abandonment and demolition, thus being prone to adaptive reuse and rapid transition to replacement with other functional areas. There are initial functions $(21,23,25-27)$ that were subject to a mix of transformations (e.g., demolition and abandonment, conversion and replacement) (Figure 8).

The maintenance is related to the initial functional uses (1-33), generally associated with the current industrial areas which are partly or entirely still in use (e.g., Electronica Plant; TURBOMECANICA; Cesarom—ceramic and porcelain tiles; Buftea, Frumusani Agrifood), but also with the transport-related functions (e.g., Otopeni International Airport; North Railway Station).

The conversion has affected former industrial or state-owned agricultural units whose physical assets have been maintained, modernized and converted into other functions: e.g., Appolo Sock Factory into Club, Climbing Room and Skate Park; Electromagnetica (electronics) into Electromagnetica Business Park; UREMOAS (radiators, metallic equipment, sanitary ware) into Renault Bucharest Connected and Coca-Cola Romania; "Cartea Românească" Printing House into Metropolis Centre (multifunctional building).

Replacement had the largest extend among the experienced spatial and functional transformations, generally affecting all functional categories that existed before 1990 (1 to 27) which were turned into the categories prevailing after 1990 (4 to 6), e.g., Titan Bread Factory with Hercesa Residence (Figure 9A); 1 Decembrie Agri-food and Greenhouses with Green City Residence (Figure 9B); Domnești Greenhouses with Curtea Domnească Residence (Figure 9C). Abandonment and demolition have affected the units subject to decline and liquidation. Most of units are entirely (e.g., Acumulatorul Factory, IPRS Băneasa, Chitila, Movila, Buftea Agri-farms, Aversa Factory) (Figure 9D) or partly (Policolor Factory, 
Republica Factory, Malaxa Plant-23 August-Faur SA) abandoned. Abandonment is multi-faced: through reinvestments and modernisation and has the potential to return to its initial function (maintenance), to shelter a new one (conversion), to be torn down (demolition) in order to make room, or most probably, to other uses (replacement) with various functional profiles. In turn, demolition has limited development directions, being prone to new functional uses (replacement) by means of newly built residential, commercial or business areas, e.g., Granitul Building Materials, Sintofarm Pharmaceutical, Danubiana Rubber Factory, Precizia Micro mechanics, IMUAB Machine Building (Figure 9E). Due to the high demand of land resources, intense spatial and functional changes occurred, especially inside the city. Thus, former units were subject to mixed transformations, e.g., UMEB (Electric Machines Plant) turned into Mall Afi Cotroceni, one of the largest in southeastern Europe, and office buildings (conversion and replacement) and Apaca Factory (textiles) has kept buildings for its original use (maintenance) and the remaining spaces were leased for other businesses (conversion) (Figure 9F).

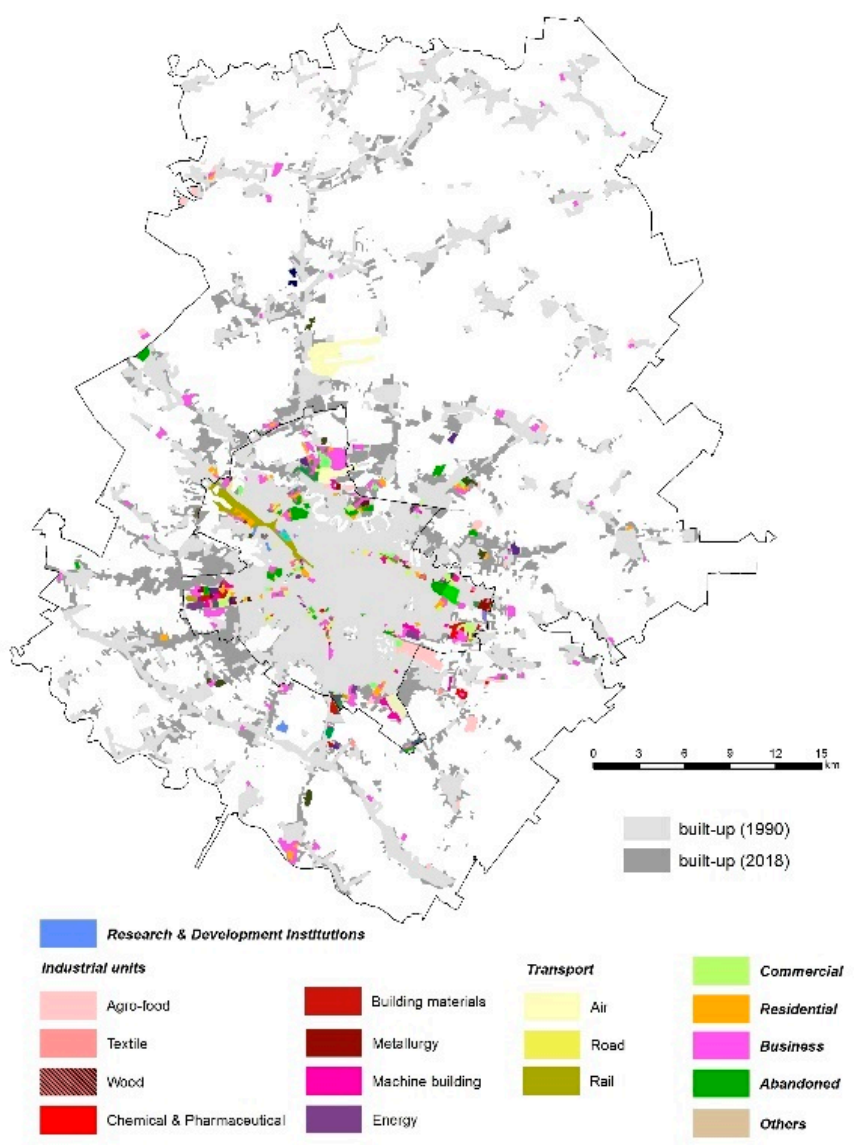

Figure 6. Spatial distribution and functional use of built industrial and agricultural sites (2018).
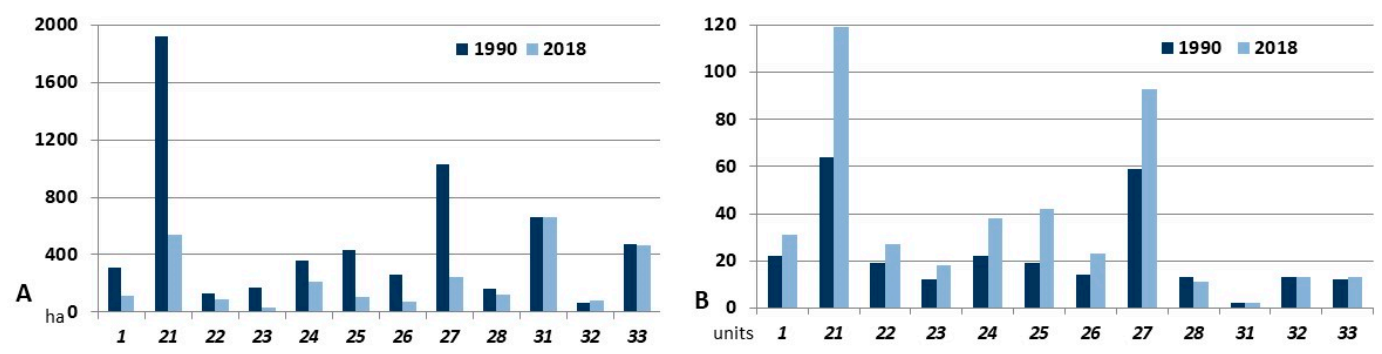

Figure 7. Spatial and functional change of built agricultural and industrial sites: shrinkage (A) and fragmentation (B). 


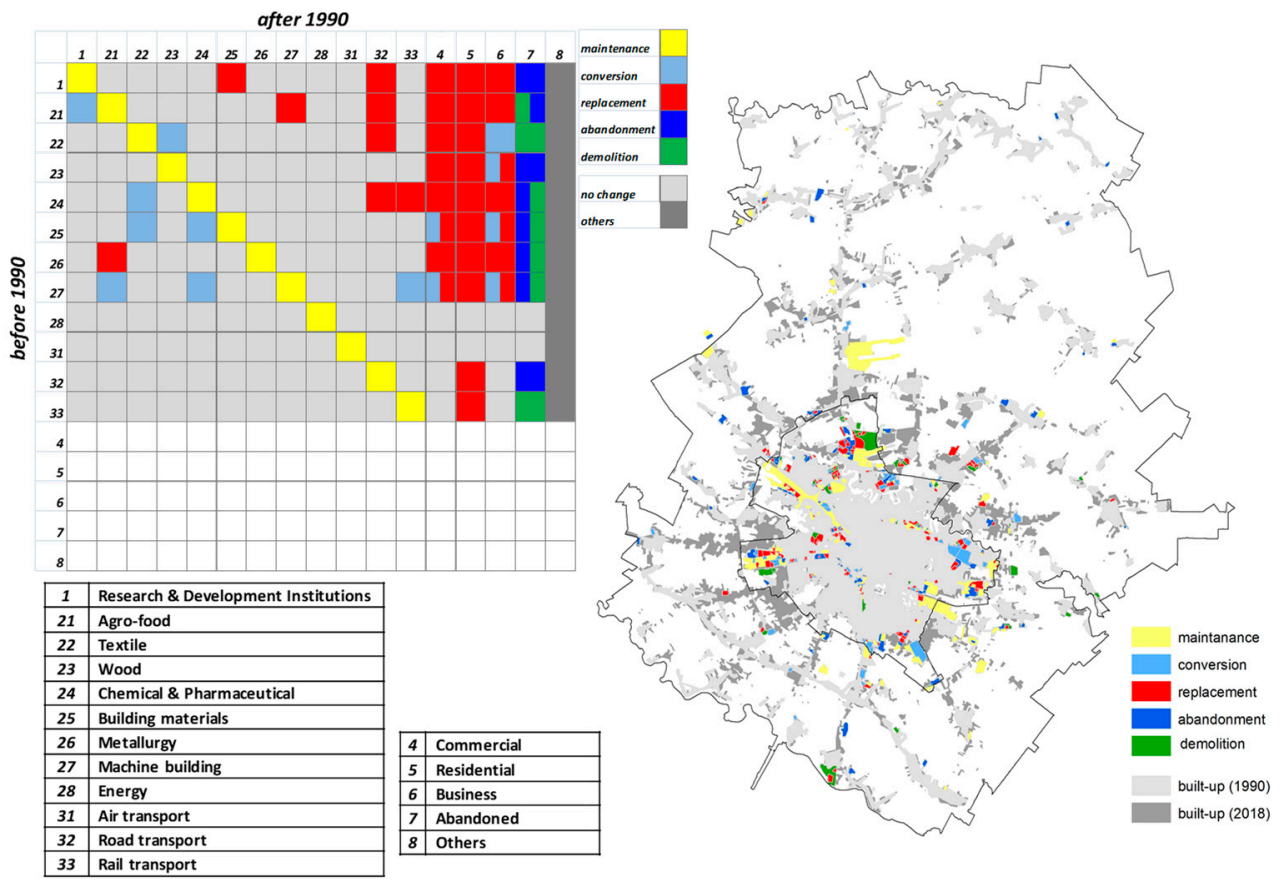

Figure 8. Functional changes and functional change matrix (1990-2018).

The investigation revealed several main features of the industrial sites after 1990 which can be summed up into: (i) significant spatial shrinkage of the overall industrial area, from the total of 6536.3 ha during the communist period, the industrial units had shrunk to more than half, that is 2791 ha; (ii) intensive fragmentation from 491 (before 1990), when the industrial units were compact and extended to 708 units (after 1990). Following the privatisation process, they were divided into smaller plots in order to be easily managed by the new owners and gradually (in most of cases) demolished and/or tuned into other destination (e.g., commercial, residential); (iii) functional diversification occurred as a natural stage following the fragmentation process and the resulted functional changes, which brings in new uses compared to the original ones (e.g., new industrial functions with diversified profiles, residential or commercial); (iv) shifting functionality from secondary to tertiary (tertiarization) is the immediate consequence of the nature of functional diversification which is roughly changing the functional profile from industrial (mainly heavy, machine building, food, textiles) to services, IT\&C, logistics, business etc.; (v) change of patterns is the overall consequence of the transition from the compact industrial pattern, generally large-sized (well-known large industrial zones or state-owned farms) to the mosaic-like pattern resulting from the first three abovementioned categories: (i) spatial shrinkage, (ii) intensive fragmentation, (iii) functional diversification and (tertiarization). After the fall of communism, in urban areas, the spatial transformation was largely associated with deindustrialization, revitalisation of the inner city, and residential and commercial suburbanisation in the outer city [5]. In the case of Bucharest, because most of the post-industrial sites are located within the city limits or at outskirts, they were subject to a continuous transformation under the high demand for land resources driven by the extended urban development. However, as shown by the current investigation, most of post-industrial sites become rapidly incorporated in the urban development process, while the valorisation of the cultural heritage provided by the former industrial buildings was not a priority. 

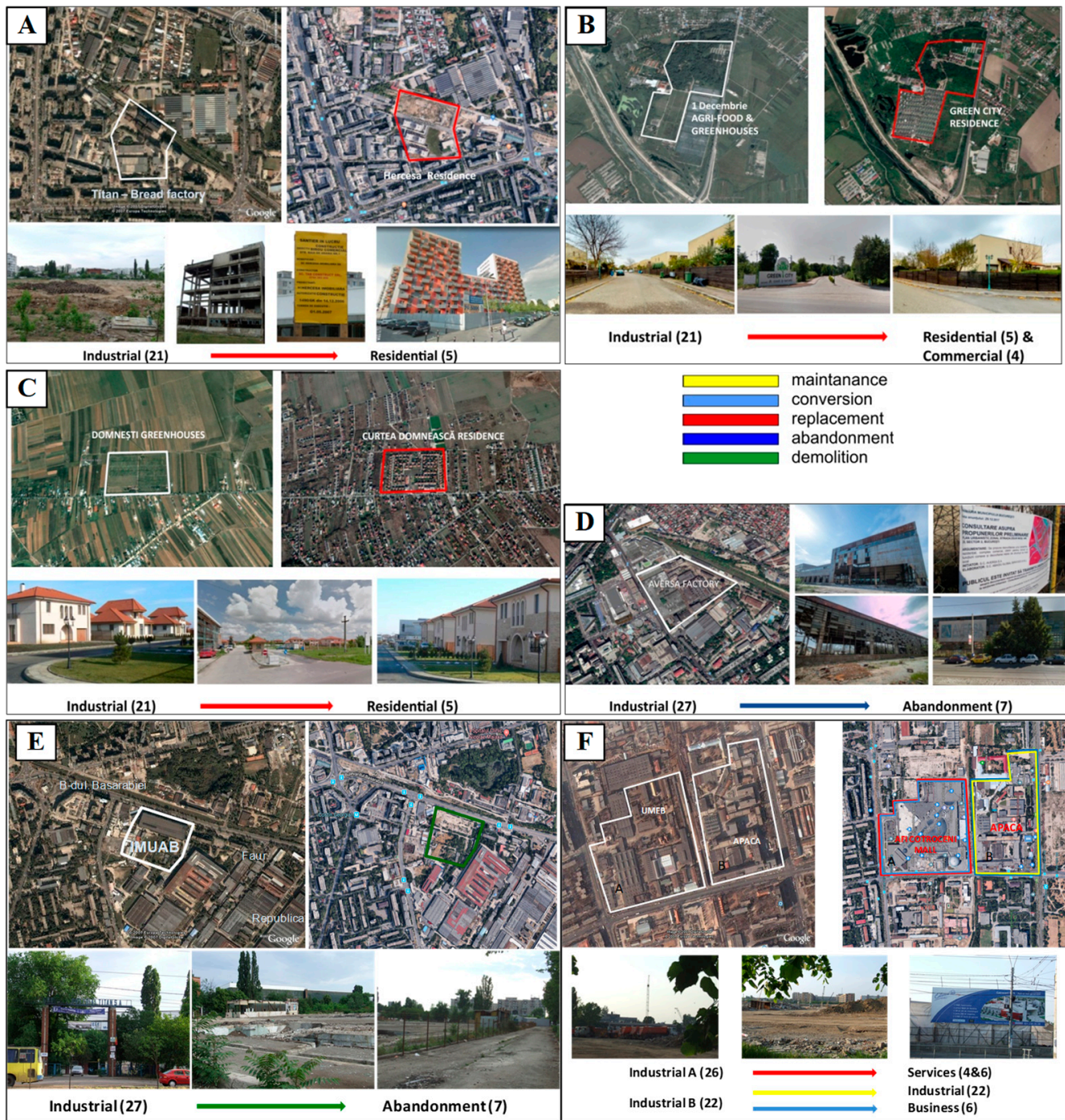

Figure 9. Examples of functional changes in the study area: (A) - Titan Bread Factory into Hercesa Residential Complex; (B)—1 Decembrie Greenhouses into Green City Residence; (C)—Domnești Greenhousese into Curtea Domnească Residence; (D)_-Aversa Factory into abandoned land; (E)— IMUAB Machine Building into abandoned land; (F)_UMEB Electric Machines Plant into Mall Afi Cotroceni and Apaca Textile Factory into industrial and business use.

\section{Discussion}

The post-communist cities are still cities in transition, subject to multiple transformation $[3,16]$, generally governed by market forces which require large land resources for new real estate investments in the development of offices, retail, residential areas. As such, processes such as land conversion have become key in providing the available land necessary to meet the market demand.

Compared to other post-communist cities that have undergone specific transformations related to deindustrialization and brownfield regeneration, i.e., Brno [11,48,55], Bucharest and its surrounding territory has been subject to mixed-use development, similar to Budapest [24-27], Warsaw [33-36] or Sofia [30-32]. Thus, the spatial and functional transformations involved new land uses associated with urban growth and sprawl (e.g., residential, business) at the expense of several land use categories: arable lands, pastures, permanent crops and agricultural complex cultivation patterns [5,6,99], forest and natural areas $[65,100]$, but also former industrial sites $[57,75,79,80]$. The last category has had an important place in the overall spatial and functional transformation of the urban and suburban landscape because most of the post-industrial sites located within Bucharest city 
limits or at outskirts, were subject to a continuous transformation and dynamics under the high demand for land resources driven by the extended urban development (urbanisation and suburbanisation). The state-owned agricultural enterprises, although located outside the city limits, are exposed to the same spatial dynamics, largely driven by residential suburbanisation. The real estate value of the physical assets (e.g., factories, halls, greenhouses) and of the land under the abandoned or demolished post-industrial units are the main drivers behind their valorisation and/or transformation into other uses, mainly residential, commercial, office buildings. In the case of large post-industrial units, i.e., the communist "industrial platforms", a chance of "viability" is represented by their transformation into industrial parks which are functional areas concentrating high-level, non-polluting activities [85]. This can generally happen in the case of the industrial platforms located at the outskirts or outside the city limits, in areas where the real estate value is not big enough to drive their transformation into other functional areas. Another way of reducing the number of abandoned or unused industrial buildings and/or preventing the demolition of cultural heritage is the adaptive reuse, which refers to the change of use of existing buildings or structures according to the needs of the new or existing owners $[1,10,101]$. As for the former state-owned agricultural enterprises, only large and coherent investment projects (i.e., EU funds) or their adaptive reuse can guarantee their preservation. However, the spatial and functional development of cities and their surrounding territories has been raising a number of conflicts between development-oriented interests and environmentally based, sometimes "conservationist", interests, such as the "sustainable city", "compact city", "self-reliant city", or "green city" [7]. It is particularly the case of Central Eastern European cities, where the spatial and functional transformations have been more dynamic and acute.

The generated real estate stock (mainly industrial) becomes an important prerequisite for the location of new functions (e.g., residential, warehouses, commercial, or office activities) [85]. Subsequently, through replacement, the new spaces are completely engulfed into the urban tissue. In both situations, the functional shift from primary and secondary to tertiary includes new specializations (e.g., services, creative industries). "Creativity" and "culture" are two policy solutions to the post-communist urban transformations [7]. Apart from being developed in the post-industrial urban contexts while addressing the rapid de-industrialisation of ex-communist cities, they also had important symbolic value of providing the innovative urban policy that most post-communist cities wish for [102]. The relocation of these creative clusters is predominantly heterogeneous, but also metropoli$\tan [62]$, which in the current situation, enacts as the relocation of companies in the outskirts or outside the city. This trend is widely identified in the post-industrial landscapes of many European cities.

\section{Conclusions}

In Romania, after the fall of communism, the spatial transformation of the urban areas is largely associated with deindustrialization, revitalisation of inner city areas and residential and commercial suburbanisation in the outer city [5]. This process has generally characterised urban areas and their surrounding territories where the industry and agricultural farms were located. The authors tried to identify and understand the changes in the spatial patterns of former built industrial and agricultural units after the fall of communism, as well as the models of adaptive reuse and their relationships with urban sprawl-related trends. In order to underline the spatial dimension of landscape transformations, the analysis revealed the state of the industrial and agricultural units before and after 1990 - a historical landmark which divides two important historical periods: communist and post-communist.

The functional change matrix highlighted not only the functional changes that agricultural and industrial sites underwent during the post-communist period, but two other important aspects such as their spatial shrinkage and fragmentation. These latter consequences are important elements that reveal the essential role they have in the future 
processes of spatial transformation of the urban fabric (urbanisation, urban regeneration and renewal). Moreover, using the functional change matrix, two main models were identified in the process of urban development in relation to the (re)use of built industrial and agricultural units: (1) heritage-oriented by way of maintenance and conversion, ensuring the continuation, reconversion and adaptive reuse; (2) urban development-oriented through the abandonment and/or demolition which can be considered as precursors of urban development (Figure 10).

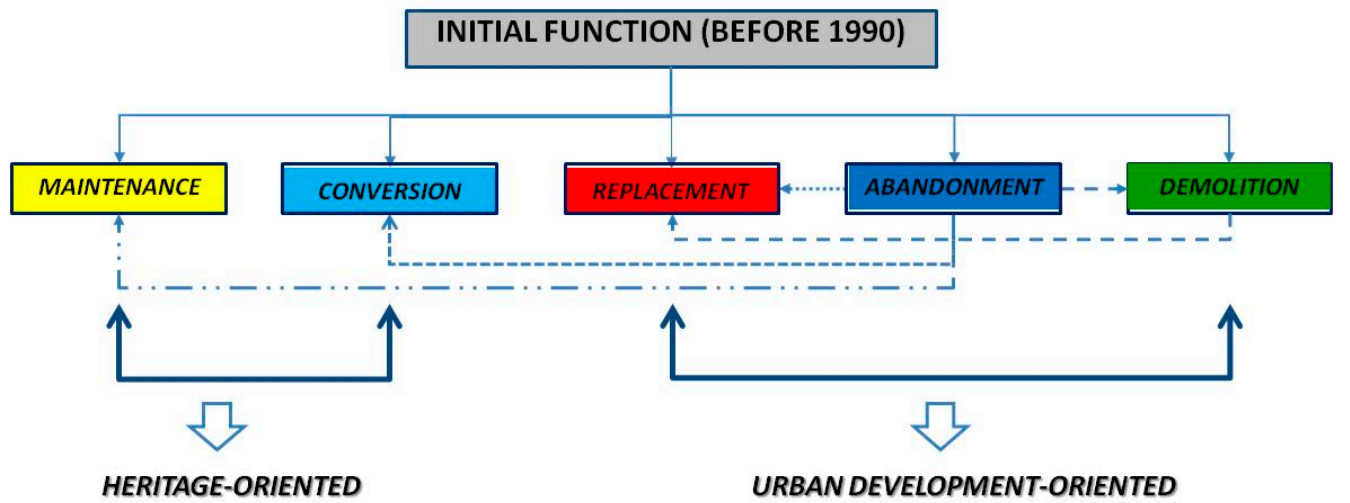

Figure 10. Functional change flows in the post-communist period.

Generally, the heritage-oriented model supports the valorisation and continuation of the former built industrial and agricultural units towards achieving sustainable and resilient urban and suburban areas through the sense of belonging and intrinsic value, the cultural identity, cultural significance of place etc. [103-105]. However, in the case of Bucharest-Ilfov development region, the extended urban development processes determined a high demand for land resources and a high pressure on agricultural assets, which were generally subject to demolition and replacement (the urban development-oriented model). In this case, the heritage-oriented model mainly refers to the industrial sites. Two illustrate examples are: "Cartea Românească" Printing House, a historical monument (code B-II-m-B-18922) built in 1919, currently operating as a multifunctional building (Metropolis Centre) (Figure 11A); Malaxa Plant-23 August-Faur SA one of the first and largest heavy machinery factories in Romania (established in 1921) with some buildings declared historical monuments (code B-II-a-A-18091) which is currently partly abandoned and converted to other uses, but with plans to establish a museum comprising historical technologies (Figure 11B).

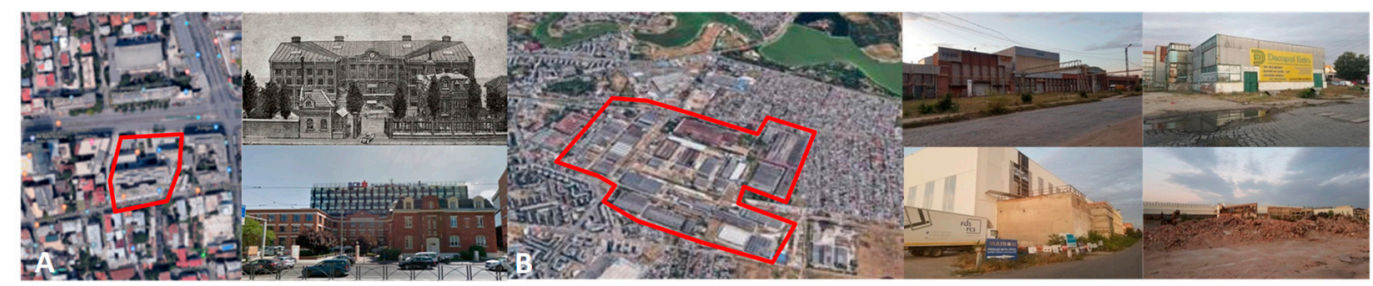

Figure 11. "Cartea Românească" Printing House, currently in Metropolis Centre (A) and Malaxa Plant-23 August-Faur SA Heavy Machinery Factory, currently mixed uses (B).

The urban development-oriented model is extremely complex; it provides a wide variety of spatial and functional changes. As exemplified in Figure 7, it has an extended spatial coverage both inside and outside the city limits. Figure 8 shows the array of functional transformations towards specific target uses driven by the urbanisation and suburbanisation processes (e.g., residential, commercial, logistic), as also exemplified in Figure 9. Within the urban development model, both industrial and agricultural built sites are involved. 
The underlying relationships between the five types of transformation are quite dynamic, especially from the abandonment stage, which can direct each abandoned unit either to heritage or urban development. However, as shown by the current investigation, most of abandoned sites have become rapidly taken in by the urban development process. The identification of already transformed sites (replacement, conversion) shows the dynamics and pattern of spatial transformations, but the detection of abandoned or demolished sites can show the direction of these transformations, key elements in the urban planning and development. The used methodology offers both an applied and a theoretical perspective for understanding the spatial and functional changes of the post-industrial and post-agricultural sites, easy to implement in various regions. It can provide best results in regions with significant socio-economic and political transformations, such as the former communist countries, where the spatial and functional changes have significantly altered the landscape.

Strengths and limitations of the present study. The proposed methodology requires accurate, historical, and recent cartographical sources to provide, as precise as possible, the spatial and functional transformations of the elements at stake. Quantitative and qualitative data on land use/cover, land use functions, demography, socio-economic characteristics etc. should be integrated to provide a more accurate picture of the change patterns and types. Thus, the current study has a number of strengths: (i) the theoretical background which is built upon the most representative studies developed in the Central Eastern European countries; (ii) the variety, reliability and scale of statistical (National Census, TEMPOline time series) and spatial data (e.g., topographic maps, satellite images) used; (iii) the visual presentation of the spatial and functional changes, along with the analysis of statistics, that can become self-explanatory tools in the planning process; (iv) the potential of the methodology of being replicated to other areas, irrespective of the spatial scale. There are, however, limitations which have been identified: (i) the limited availability of accurate geospatial data (topographic maps, cadastral maps, satellite images) for the analysed periods, which requires the use of different years to better illustrate the analysed elements; (ii) the limited availability of up-to-date statistical data at an LAU level necessary to explain the socio-economic context of the spatial and functional changes; there are indicators that would have been beneficial, but could not be included in the current study, i.e., employment by branch of economic activity before 1990 and in 2018. Thus, the outcomes of the current study support identifying areas prone to future development through the adaptive (re)use of former built-up land (agricultural or industrial) in order to predict future urban growth spatial trends and patterns inside and outside the city limits.

Author Contributions: Conceptualization, I.G., C.D. (Cristina Dumitrică), and M.D.; methodology, I.G., C.D. (Cristina Dumitrică), B.M.; validation, C.D. (Cristina Dumitrică), and C.D. (Costin Dumitrașcu); formal analysis, M.D. and B.M.; investigation, M.D., B.M., and C.D. (Costin Dumitrașcu); resources, C.D. (Cristina Dumitrică); writing_original draft preparation, I.G.; writing—review and editing, I.G. and B.M.; visualization, C.D. (Cristina Dumitrică) and M.D.; supervision, I.G. All authors have read and agreed to the published version of the manuscript.

Funding: This research received no external funding.

Data Availability Statement: Data sharing not applicable.

Acknowledgments: The current study was carried out within the framework of the projects entitled "Geographical study of the man-environment relationships in the Romanian Metropolitan Areas" and "Atlas of Environment", as part of the Research Plan of the Institute of Geography, Romanian Academy.

Conflicts of Interest: The authors declare no conflict of interest. 


\section{References}

1. Mengüşoğlu, N.; Boyacioğlu, E. Reuse of industrial built heritage for residential purposes in Manchester. METU J. Fac. Archit. 2016, 30, 117-138.

2. Popovici, E.A.; Bălteanu, D.; Kucsicsa, G. Assessment of changes in land-use and land-cover pattern in Romania using Corine Land Cover Database. Carpath. J. Earth Environ. 2013, 8, 195-208.

3. Garcia-Ayllon, S. Urban transformations as indicators of economic change in post-communist Eastern Europe: Territorial diagnosis through five case studies. Habitat Int. 2017, 71, 29-37. [CrossRef]

4. Mitrică, B.; Grigorescu, I.; Urucu, V. Dezvoltarea Urbană și Ariile Metropolitane. In Romania—Natură și Societate; Bălteanu, D., Dumitraşcu, M., Geacu, S., Mitrică, B., Sima, M., Eds.; The Publishing House of the Romanian Academy: Bucharest, Romania, 2016; pp. 250-291. (In Romanian)

5. $\quad$ Grigorescu, I.; Kucsicsa, G.; Popovici, E.-A.; Mitrică, B.; Dumitraşcu, M.; Mocanu, I. Regional disparities in the urban sprawl phenomenon in Romania using Corine Land Cover database. Rev. Roum. Géogr./Rom. Journ. Geogr. 2018, 62, $169-184$.

6. Grigorescu, I.; Kucsicsa, G.; Popovici, E.A.; Mitrică, B.; Mocanu, I.; Dumitraşcu, M. Modelling land use/cover change to assess future urban sprawl in Romania. Geocarto Int. 2021, 36, 721-739. [CrossRef]

7. Buček, J. Urban Development Policy Challenges in East-Central Europe: Governance, City Regions and Financialisation. Quaest. Geogr. 2016, 35, 7-26. [CrossRef]

8. Nuissl, H.; Siedentop, S. Urbanisation and Land Use Change. In Sustainable Land Management in a European Context, HumanEnvironment Interactions; Weith, T., Barkmann, T., Gaasch, N., Rogga, S., Strauß, C., Zscheischler, J., Eds.; Springer: Cham, Switzerland, 2021; Volume 8, pp. 75-99.

9. Loures, L. Post-industrial landscapes as drivers for urban redevelopment: Public versus expert perspectives towards the benefits and barriers of the reuse of post-industrial sites in urban areas. Habitat Int. 2015, 45, 72-81. [CrossRef]

10. Bottero, M.; D'Alpaos, C.; Oppio, A. Ranking of Adaptive Reuse Strategies for Abandoned Industrial Heritage in Vulnerable Contexts: A Multiple Criteria Decision Aiding Approach. Sustainability 2019, 11, 785. [CrossRef]

11. Osman, R.; Frantal, B.; Klusáček, P.; Kunc, J.; Martinát, S. Factors affecting brownfield regeneration in post-socialist space: The case of the Czech Republic. Land Use Policy 2015, 48, 309-316. [CrossRef]

12. Sýkora, L.; Ourednicek, M. Sprawling post-communist metropolis: Commercial and residential suburbanisation in Prague and Brno, the Czech Republic. In Employment Deconcentration in European Metropolitan Areas; Razin, E., Dijst, M., Vázquez, C., Eds.; Springer: Heidelberg, Germany, 2007; Volume 91, pp. 209-233.

13. Tosics, I. City development in central and eastern Europe since 1990: The impacts of internal forces. In Transformation of Cities in Central and Eastern Europe: Towards Globalisation; Hamilton, F.E.I., Dimitrowska-Andrews, K., Pichler-Milanovic', N., Eds.; United Nations University Press: Tokyo, Japan, 2005; pp. 44-78.

14. Tsenkova, S.; Nedovic-Budic, Z. The Urban Mosaic of Post-Socialist Europe: Space, Institutions and Policy; Springer Science \& Business Media: Heidelberg, Germany, 2006.

15. Sýkora, L. Post-socialist cities. In International Encyclopedia of Human Geography, 1st ed.; Elsevier: Oxford, UK, 2009; Volume 8, pp. 387-395.

16. Sýkora, L.; Bouzarovski, S. Multiple transformations: Conceptualising the post-communist urban transition. Urban Stud. 2012, 49, 43-60. [CrossRef]

17. Sýkora, L.; Stanilov, K. The challenge of post-socialist suburbanisation. In Confronting Suburbanisation: Urban Decentralization in Post-Socialist Central and Eastern Europe; Sýkora, L., Stanilov, K., Eds.; Wiley Blackwell: Oxford, UK, 2014; pp. 1-32.

18. Malý, J.; Dvořák, P.; Šuška, P. Multiple transformations of post-socialist cities: Multiple outcomes? Cities 2020, $107,102901$. [CrossRef]

19. Haase, A.; Wolff, M.; Špačková, P.; Radzimski, A. Reurbanisation in Post-socialist Europe - A ComparativeView of Eastern Germany, Poland, and the Czech Republic. Comp. Popul. Stud. 2017, 42, 353-389. [CrossRef]

20. Idczak, P.; Musiałkowska, I.; Mrozik, K. Ecosystem services in the appraisal of the economic performance of urban regeneration projects exemplified by the Jessica Initiative. Econ. Environ. 2019, 70, 114-129.

21. Jadach-Sepioło, A.; Zathey, M. Alternative between Revitalisation of City Centres and the Rising Costs of Extensive Land Use from a Polish Perspective. Land 2021, 10, 488. [CrossRef]

22. Ouředníček, M. Differential suburban development in the Prague urban region. Geogr. Ann. Ser. B, Hum. Geogr. 2007, 89, 111-126. [CrossRef]

23. Pazur, R.; Feranec, J.; Stych, P.; Kopecká, M.; Holman, L. Changes of urbanised landscape identified and assessed by the Urban Atlas data: Case study of Prague and Bratislava. Land Use Policy 2017, 61, 135-146. [CrossRef]

24. Kok, H.; Kovacs, Z. The process of suburbanisation in the agglomeration of Budapest. J. Hous. Built Environ. 1999, 14, $119-141$.

25. Soós, G.; Ignits, G. Suburbanisation and its consequences in the Budapest metropolitan area. In Proceedings of the 3rd Euro Conference The European City in Transition, The City and the Region, Weimar, Germany, 14-15 November 2003.

26. Tosics, I. Spatial Restructuring in Post-Socialist Budapest; Physica-Verlag: Heidelberg, Germany, 2006; pp. 131-150.

27. Kovács, Z.; Farkas, J.Z.; Egedy, T.; Kondor, A.C.; Szabó, B.; Lennert, J.; Baka, D.; Kohán, B. Urban sprawl and land conversion in post-socialist cities: The case of metropolitan Budapest. Cities 2019, 92, 71-81. [CrossRef]

28. Tammaru, T.; Leetmaa, K.; Silm, S.; Ahas, R. Temporal and Spatial Dynamics of the New Residential Areas around Tallinn. Eur. Plan. Stud. 2009, 17, 423-439. [CrossRef] 
29. Leetmaa, K.; Kährik, A.; Nuga, M.; Tammaru, T. Suburbanisation in the Tallinn metropolitan area. In Confronting Suburbanisation: Urban Decentralization in Post-Socialist Central and Eastern Europe; Wiley Blackwell: Oxford, UK, 2014; pp. 192-224.

30. Hirt, S. Post-Socialist Urban Forms: Notes From Sofia. Urban. Geogr. 2006, 27, 464-488. [CrossRef]

31. Hirt, S. Suburbanising Sofia: Characteristics of post-socialist peri-urban change. Urban Geogr. 2007, 28, 755-780. [CrossRef]

32. Hirt, S.; Kovachev, A. The changing spatial structure of post-socialist Sofia. In The Urban Mosaic of Post-Socialist Europe: Space, Institutions and Polic; Tsenkova, S., Nedovic-Budic, Z., Eds.; Springer Science \& Business Media: Heidelberg, Germany, 2006; pp. 113-130.

33. Degórska, B. Spatial growth of urbanised land within the Warsaw Metropolitan Area in the first decade of the 21st century. Geogr. Pol. 2012, 85, 77-95. [CrossRef]

34. Sławiński, T.; Sulmicki, M. The 3S Model of Urban Sprawl in the Warsaw Functional Area. MAZOWSZE Stud. Reg. 2015, 17, 53-65.

35. Mantey, D.; Sudra, P. Types of suburbs in post-socialist Poland and their potential for creating public spaces. Cities 2018, 88, 209-221. [CrossRef]

36. Sudra, P. Spatial dispersion and the concentration of buildings in an urban agglomeration-A typology proposal for the Warsaw Metropolitan Area. Environ. Socio-Econ. Stud. 2020, 8, 81-96. [CrossRef]

37. Gyurkovich, M.; Gyurkovich, J. New Housing Complexes in Post-Industrial Areas in City Centres in Poland versus Cultural and Natural Heritage Protection-With a Particular Focus on Cracow. Sustainability 2021, 13, 418. [CrossRef]

38. Szubert, M.; Warcholik, W.; Żemła, M. The Influence of Elements of Cultural Heritage on the Image of Destinations, Using Four Polish Cities as an Example. Land 2021, 10, 671. [CrossRef]

39. Kirschke, K.; Kirschke, P.; Komarzyńska-Świeściak, E. Adaptive reuse of commercial and public buildings in Wroclaw Old Town in Poland. The occupant's safety and comfort versus preservation of authenticity of monumental buildings. Teka Kom. Archit. Urban. Studiów Krajobrazowych 2018, 14, 24-41. [CrossRef]

40. Szmytkie, R. Suburbanisation processes within and outside the city: The development of intra-urban suburbs in Wrocław, Poland. Morav. Geogr. Rep. 2021, 29, 149-165. [CrossRef]

41. Mrozik, K.; Podawca, K.; Drożyńska, D. Spatial diversification of the implementation of planning and investment processes in the Poznań Metropolitan Area. Ekon. Sr. 2020, 4, 64-80.

42. Grigorescu, I.; Mitrică, B.; Mocanu, I.; Ticană, N. Urban sprawl and residential development in the Romanian Metropolitan Areas. Rev. Roum. Géogr./Rom. J. Geogr. 2012, 56, 43-59.

43. Mihai, B.; Nistor, C.; Simion, G. Post-socialist urban growth of Bucharest, Romania-A change detection analysis on Landsat imagery (1984-2010). Acta Geogr. Slov. 2015, 55, 223-234. [CrossRef]

44. Dumitrache, L.; Zamfir, D.; Nae, M.; Simion, G.; Stoica, I.V. The Urban Nexus: Contradictions and Dilemmas of (Post) Communist (Sub) Urbanisation in Romania. Human Geogr. 2016, 10, 39-58. [CrossRef]

45. Grigorescu, I.; Kucsicsa, G.; Mitrică, B.; Mocanu, I.; Dumitraşcu, M. Regional Spatial and Statistical Analyses of the Urban-rural Relationships in Romania. Case Study: Romanian Plain. In Smart Geography; Nedkov, S., Zhelezov, G., Ilieva, N., Nikolova, M., Koulov, B., Naydenov, K., Dimitrov, S., Eds.; Springer: Cham, Switzerland, 2020; pp. 155-173.

46. Kucsicsa, G.; Grigorescu, I. Urban Growth in the Bucharest Metropolitan Area: Spatial and Temporal Assessment Using Logistic Regression. J. Urban. Plan. Dev. 2018, 144, 05017013. [CrossRef]

47. Stoica, I.-V.; Vîrghileanu, M.; Zamfir, D.; Mihai, B.-A.; Săvulescu, I. Comparative Assessment of the Built-Up Area Expansion Based on Corine Land Cover and Landsat Datasets: A Case Study of a Post-Socialist City. Remote. Sens. 2020, 12, 2137. [CrossRef]

48. Frantal, B.; Greer-Wootten, B.; Klusáček, P.; Krejčí, T.; Kunc, J.; Martinát, S. Exploring spatial patterns of urban brownfields regeneration: The case of Brno, Czech Republic. Cities 2015, 44, 9-18. [CrossRef]

49. Spórna, T. The suburbanisation process in a depopulation context in the Katowice conurbation, Poland. Environ. Socio-Econ. Stud. 2018, 6, 57-72. [CrossRef]

50. Kerstetter, D.; Confer, J.; Bricker, K. Industrial Heritage Attractions: Types and Tourists. J. Travel Tour. Mark. 1998, 7, 91-104. [CrossRef]

51. Landorf, C. A Framework for Sustainable Heritage Management: A Study of UK Industrial Heritage Sites. Int. J. Heritage Stud. 2009, 15, 494-510. [CrossRef]

52. Veldpaus, L.; Roders, A.R.P.; Colenbrander, B.J.F. Urban Heritage: Putting the Past into the Future. Hist. Environ. Policy Pract. 2013, 4, 3-18. [CrossRef]

53. Chen, J.; Judd, B.; Hawken, S. Adaptive reuse of industrial heritage for cultural purposes in Beijing, Shanghai and Chongqing. Struct. Surv. 2016, 34, 331-350. [CrossRef]

54. Zhang, C.; Lin, S.; Gao, L. The Role of Community in Industrial Heritage Redevelopment: Evidence from Taigucang Wharf, Guangzhou, China. Asian J. Tour. Res. 2016, 1, 147-166. [CrossRef]

55. Navratil, J.; Krejci, T.; Martinat, S.; Pasqualetti, M.J.; Klusacek, P.; Frantal, B.; Tochackova, K. Brownfields do not "only live twice": The possibilities for heritage preservation and the enlargement of leisure time activities in Brno, the Czech Republic. Cities 2018, 74, 52-63. [CrossRef]

56. Frantál, B.; Kunc, J.; Nováková, E.; Klusáček, P.; Martinát, S.; Osman, R. Location Matters! Exploring Brownfields Regeneration in a Spatial Context (A Case Study of the South Moravian Region, Czech Republic). Morav. Geogr. Rep. 2013, 21, 5-19. [CrossRef] 
57. Cercleux, A.-L.; Merciu, F.-C.; Merciu, G.-L. Models of Technical and Industrial Heritage Re-Use in Romania. Procedia Environ. Sci. 2012, 14, 216-225. [CrossRef]

58. Copić, S.; Tumarić, A. Possibilities of industrial heritage reuse as tourist attractions: A case study of city of Zrenjanin (Vojvodina, Serbia). Geogr. Pannonica 2015, 19, 44-49. [CrossRef]

59. Iancu, F.; Stoica, I. Tourist capitalization of industrial heritage elements: A strategic direction of sustainable development. Case study: Petrosani depression. GeoJ Tour. 2010, 5, 62-70.

60. Filimon, L.; Nemes, V.; Olau, P. Urban regeneration in the context of current urban development policies in Romania. Case study: Ştei city (Bihor county, Romania). Rev. Rom. Geogr. Pol. 2012, XIV, 200-210.

61. Boix, R.; Hervás-Oliver, J.L.; De-Miguel-Molina, B. Micro-geographies of creative industries clusters in Europe: From hot spots to assemblages. Pap. Reg. Sci. 2014, 94, 753-772. [CrossRef]

62. Zhong, S. Artists and Shanghai's culture-led urban regeneration. Cities 2016, 56, 165-171. [CrossRef]

63. Boca, M.C. Urban regeneration and gentrification in Romania. J. Geogr. Politi- Soc. 2018, 8, 2731. [CrossRef]

64. Boca, M.C. Theoretical and practical aspects of regeneration of decommissioned industrial areas in Oradea, Romania. J. Geogr. Politi-Soc. 2019, 9, 33-38. [CrossRef]

65. Grigorescu, I.; Geacu, S. The dynamics and conservation of forest ecosystems in Bucharest Metropolitan Area. Urban. For. Urban. Green. 2017, 27, 90-99. [CrossRef]

66. Evans, G. Creative Cities, Creative Spaces and Urban Policy. Urban. Stud. 2009, 46, 1003-1040. [CrossRef]

67. Zheng, J.; Chan, R. The impact of 'creative industry clusters' on cultural and creative industry development in Shanghai. City, Cult. Soc. 2014, 5, 9-22. [CrossRef]

68. Sugden, E. The Adaptive Reuse of Industrial Heritage Buildings: A Multiple-Case Studies Approach. Master's Thesis, University of Waterloo, Waterloo, ON, Canada, 2018.

69. Langston, C.; Wong, F.K.; Hui, E.C.M.; Shen, L.-Y. Strategic assessment of building adaptive reuse opportunities in Hong Kong. Build. Environ. 2008, 43, 1709-1718. [CrossRef]

70. Klusáček, P.; Alexandrescu, F.; Osman, R.; Malý, J.; Kunc, J.; Dvořák, P.; Frantal, B.; Havlíček, M.; Krejčí, T.; Martinát, S.; et al. Good governance as a strategic choice in brownfield regeneration: Regional dynamics from the Czech Republic. Land Use Policy 2018, 73, 29-39. [CrossRef]

71. Tan, Y.; Shen, L.-Y.; Langston, C. A fuzzy approach for adaptive reuse selection of industrial buildings in Hong Kong. Int. J. Strat. Prop. Manag. 2014, 18, 66-76. [CrossRef]

72. Vardopoulos, I. Critical sustainable development factors in the adaptive reuse of urban industrial buildings. A fuzzy DEMATEL approach. Sustain. Cities Soc. 2019, 50, 101684. [CrossRef]

73. Filip, S.; Cocean, P. Urban industrial brownfields: Constraints and opportunities in Romania. Carpath J. Earth Environ. 2012, 7, 155-164.

74. Merciu, F.C.; Cercleux, A.L.; Peptenatu, D.; Merciu, G.L.; Pintilii, R.; Drăghici, C.C. Revival of industrial towns through cultural regeneration-a viable solution. In Proceedings of the 1st International Conference on Tourism and Economic Development (TED '11), Drobeta-Turnu Severin, Romania, 27-29 October 2011; pp. 27-29.

75. Merciu, F.-C.; Merciu, G.-L.M.; Cercleux, A.-L.; Drăghici, C. Conversion of industrial heritage as a vector of cultural regeneration. Procedia. Soc. Behav. Sci. 2014, 122, 162-166.

76. Cobârzan, B. Brownfield redevelopment in Romania. Transylv. Rev. Adm. Sci. 2007, 3, $28-46$.

77. Popescu, G.; Patraşcoiu, R. Brownfield sites - between abandonment and redevelopment case study: Craiova city. Hum. Geogr. - J. Stud. Res. Hum. Geogr. 2012, 6, 91-97. [CrossRef]

78. Moscovici, A.M.; Banescu, O.A.; Vaduva, R. Integrating brownfield sites into city redevelopment strategies. In Proceedings of the 17th International Multidisciplinary Scientific GeoConference, Surveying Geology \& Mining, Albena, Bulgaria, 29 June-5 July 2017; Volume 17, pp. 675-682.

79. Simion, G. Effects of post-socialist deindustrialization in Central and Eastern Europe: Results of an industrial site survey and GIS mapping in Bucharest City, Romania. Hum. Geogr. 2016, 10, 64-76.

80. Moţcanu-Dumitrescu, M.A. Bucharest Municipality competitive local economic development through urban regeneration of destructured industrial areas. Urbanism. Arhitectură. Construcții 2015, 6, 37-56.

81. Jucu, I.S. Romanian Post-socialist Industrial Restructuring at the Local Scale: Evidence of Simultaneous Processes of De/Reindustrialization in the Lugoj Municipality of Romania. J. Balk. Near East. Stud. 2015, 17, 408-426. [CrossRef]

82. Georgescu, L.P.; Iticescu, C.; Murariu, G.; Topa, C. Ecological revitalisation of brownfields-a challenge for Romania and Eastern Europe. J. Food Agric. Environ. 2014, 12, 503-507.

83. Constantinescu, I.P.; Dascălu, D.; Sucală, C. An Activist Perspective on Industrial Heritage in Petrila, a Romanian Mining City. Public Hist. 2017, 39, 114-141. [CrossRef]

84. Huzui, A.E.; Mirea, D.A.; Stoiculescu, R.C. The perception upon landscape revitalization of industrial spaces. Case study: The industrial units Belvedere Cigarette Factory and SC Mefin Sinaia. Rom. Rev. Reg. Stud. 2011, 7, 67-78.

85. Popescu, C. Industrializarea României-de la Dezindustrializare la Reindustrializare. In Romania; The Publishing House of the Romanian Academy: Bucharest, Romania, 2016; pp. 375-404. (In Romanian)

86. Nae, M.; Dumitrache, L.; Suditu, B.; Matei, E. Housing Activism Initiatives and Land-Use Conflicts: Pathways for Participatory Planning and Urban Sustainable Development in Bucharest City, Romania. Sustainability 2019, 11, 6211. [CrossRef] 
87. Bălteanu, D.; Popescu, M.; Popovici, E.A. Agriculture. In Romania; The Publishing House of the Romanian Academy: Bucharest, Romania, 2006; pp. 228-235.

88. Popovici, E.A.; Bălteanu, D.; Kucsicsa, G. Utilizarea Terenurilor și Dezvoltarea Actuală a Agriculturii. In Romania; The Publishing House of the Romanian Academy: Bucharest, Romania, 2016; pp. 329-374. (In Romanian)

89. Ianoş, I.; Tălângă, C.; Braghină, C.; Gheorghe, C.A. Characteristics of the industrialization process around the moment of collapse of a centralized political system. Romania as a case study. Forum Geogr. 2010, 9, 161-172.

90. Popescu, C. Industrial Restructuring. In Romania; The Publishing House of the Romanian Academy: Bucharest, Romania, 2006; pp. 236-256.

91. Popescu, C. Deindustrialization and urban shrinkage in Romania. What lessons for the spatial policy? Transylv. Rev. Adm. Sci. 2014, 10, 181-202.

92. Săgeată, R.; Popescu, C.Regiunile de Dezvoltare şi Politica de Dezvoltare Regională. In Romania; The Publishing House of the Romanian Academy: Bucharest, Romania, 2016; pp. 604-608. (In Romanian)

93. Grigorescu, I.; Sima, M.; Mitrică, B.; Kucsicsa, G.; Dumitraşcu, M. A regional assessment of the man-made hazards. The case of Bucharest-Ilfov Development Region. In Proceedings of the 17th International Multidisciplinary Scientific GeoConference vol. 5 Ecology and Environmental Protection, Albena, Bulgaria, 29 June-5 July 2017; pp. 15-22.

94. Bălteanu, D.; Mitrică, B.; Mocanu, I.; Sima, M.; Popescu, C. Caracterizarea Geografică a Regiunilor de Dezvoltare. In Romania; The Publishing House of the Romanian Academy: Bucharest, Romania, 2016; pp. 621-652. (In Romanian)

95. Mitrică, B. Changes in the dynamics and demographic structures of the Romanian urban population. An overview of the post-communist period. Romanian J. Geogr. 2014, 58, 201-212.

96. Mitrică, B.; Persu, M.R.; Mocanu, I.; Şerban, P.; Grigorescu, I.; Damian, N. Changes in the Dynamics and Demographic Structure of the Romanian Rural Population: An Overview of the Post-communist Period, in vol. In Three Decades of Transformation in the East-Central European Countryside; Banski, J., Ed.; Springer: Heidelberg, Germany, 2019; pp. 191-215.

97. Stănculescu, M.S.; Berevoiescu, I. Sărac Lipit, Caut Altă Viață! Fenomenul Sărăciei Extreme și al Zonelor Sărace în România; Nemira Publishing House: Bucharest, Romania, 2004.

98. Erdeli, G.; Simion, G. Local Decentralization and extended suburbanisation: A geographical approach of the metropolisation process in Romania. Bul. Soc. Geogr. Rom. 2006, XII, 107-120.

99. Grădinaru, S.R.; Ioja, I.-C.; Onose, D.A.; Gavrilidis, A.A.; Pătru-Stupariu, I.; Kienast, F.; Hersperger, A.M. Land abandonment as a precursor of built-up development at the sprawling periphery of former socialist cities. Ecol. Indic. 2015, 57, 305-313. [CrossRef]

100. Kucsicsa, G.; Popovici, E.A.; Bălteanu, D.; Dumitraşcu, M.; Grigorescu, I.; Mitrică, B. Assessing the Potential Future Forest-Cover Change in Romania, Predicted Using a Scenario-Based Modelling. Environ. Model. Assess 2019, 25, 471-491. [CrossRef]

101. Wilkinson, S.; James, K.; Reed, R. Using building adaptation to deliver sustainability in Australia. Struct. Surv. 2009, $27,46-61$. [CrossRef]

102. Bullen, P.A.; Love, P. Adaptive reuse of heritage buildings. Struct. Surv. 2011, 29, 411-421. [CrossRef]

103. De Medici, S.; De Toro, P.; Nocca, F. Cultural Heritage and Sustainable Development: Impact Assessment of Two Adaptive Reuse Projects in Siracusa, Sicily. Sustainability 2019, 12, 311. [CrossRef]

104. Aigwi, I.E.; Ingham, J.; Phipps, R.; Filippova, O. Identifying parameters for a performance-based framework: Towards prioritising underutilised historical buildings for adaptive reuse in New Zealand. Cities 2020, 102, 102756. [CrossRef]

105. Borén, T.; Young, C. Conceptual export and theory mobilities: Exploring the reception and development of the "creative city thesis" in the post-socialist urban realm. Eurasian Geogr. Econ. 2016, 57, 588-606. [CrossRef] 